\title{
CHANGES THE CONCENTRATION OF SELECTED PAHS IN URBAN SOILS FERTILIZED WITH MUNICIPAL SEWAGE SLUDGE
}

\author{
Urszula Wydro', Elżbieta Wołejko', Tadeusz Łoboda', Małgorzata Kowczyk-Sadowy² \\ 1 Division of Sanitary Biology and Biotechnology, Bialystok University of Technology, Wiejska 45E Str., 15-351 \\ Białystok, Poland, e-mail: uwydro@gmail.com \\ 2 Division of Chemistry, Bialystok University of Technology, Wiejska 45E Str., 15-351 Białystok, Poland
}

Received: 2015.08.15

Accepted: 2015.10.06

Published: 2015.11.10

\begin{abstract}
The aim of this study was to analyze changes in the content of selected polycyclic aromatic hydrocarbons (PAHs) in urban soils fertilized with municipal sewage sludge. The factors in the experiment were three lawns along the main roads in Bialystok (in Popieluszki, Hetmanska and Raginisa Strs.), doses of sewage sludge (0 - control; 75 and $150 \mathrm{Mg} / \mathrm{ha}$ ) and two years of study (2011 and 2012). The studied parameters were monitored at the end of the growing season (in October 2011 and 2012) by determining fluoranthene, pyrene, benzo[a]anthracene, chrysene, and benzo[a]pyrene in soil samples. Furthermore, the dehydrogenase activity, the $\mathrm{pH}$ and organic carbon content of the soil were determined. Obtained content of studied PAHs in the urban soil does not exceed those contained in the Regulation of the Minister of the Environment of September $9^{\text {th }}, 2002$ on soil quality standards and ground quality standards. The concentration of pyrene and chrysene differed significantly depending on the time of sampling and the localization. It has been shown that fertilization of soil sewage sludge revealed reduction of pyrene concentration in soil. Among 5 tested PAHs compounds, benzo[a]pyrene was the most dominant compound both in samples collected in 2011 and 2012 (28 and $27 \%$ respectively).
\end{abstract}

Keywords: fluoranthene, pyrene, benzo[a]anthracene, chrysene, benzo[a]pyrene, urban soil, sewage sludge.

\section{INTRODUCTION}

Heavy metals and PAHs are considered the most common and potentially harmful contaminants in soil in areas affected by anthropogenic pollution [Baran et al. 2004].

PAHs are considered one of the most dangerous groups of pollutants for living organisms due to their carcinogenic and mutagenic properties. They are formed during anthropogenic activity such as incomplete burning of fossil fuels, wood and solid wastes and can enter soil via atmospheric deposition [Wild and Jones 1995, Dębska et al. 2014]. Sixteen PAHs have been identified as priority pollutants by both China and the United States Environmental Protection Agency (US EPA), and seven of them are considered probable carcinogens, i.e. benzo[a]anthracene (BaA), chrysene (CHR), benzo[a]pyrene (BaP). The European Union has established a threshold value for benzo[a]pyrene in the air [Wang et al. 2012, De Nicola et al. 2014].

Stability of PAHs in the soil is also dependent on the structure and properties of hydrocarbons [Banach-Szott et al 2012]. Usually, low-molecular-weight PAHs are easily degradable, but highmolecular weight PAHs, containing four or more aromatic rings, are considered resistant, thermodynamically stable and more difficult to degrade [Rosales et al 2012].

Soils in urban areas are usually characterized by high content of PAHs. Such amounts of PAHs in urban soils are associated with the presence of both stationary sources (power plants, industry and residential heating) and diffuse sources (traffic emissions and products resulting from 
the abrasion of tires and asphalt components) [Banger et al 2010, Piekutin 2011]. These compounds are strongly hydrophobic and lipophilic as well as having a propensity to accumulate in plant and animal tissues [Vane et al. 2014]. PAHs introduced into the soil can adversely affect microorganisms, what can be manifested in changes in enzymatic and microbial activity of soil [Baran et al. 2004]. Proximity of soils contaminated with PAHs may increase the probability of human exposure to these contaminants through inhalation, ingestion or dermal contact [Banger et al 2010].

The aim of this work was to investigate the impact of localization of studied lawns and sewage sludge fertilization on selected PAHs concentrations in the urban soil in Bialystok.

\section{MATERIAL AND METHODS}

Three experiments on the lawns along the main roads of Bialystok: Hetmanska Str., Popieluszki Str. and Raginisa Str. were founded. The factors of the experiment were: three doses of sewage sludge ( 0 - control, 75 and $150 \mathrm{Mg} / \mathrm{ha}$ ) and two years of research (2011 and 2012).

The characteristics of research objects location are as follows:

- in Popieluszki Str. - single lane carriageways central reservation on the outskirts of the northern part of the city, at a distance of 5 and $15 \mathrm{~m}$ from the road;

- in Hetmanska Str. - single lane carriageways central reservation on the outskirts of the southern part of the city, at a distance of 1 and $1.5 \mathrm{~m}$ from the road;

- in Raginisa Str. - roadside one-lane road on the outskirts of the northern part of the city (the area of housing estate), distance was 15 $\mathrm{m}$ from the road.

The volume of vehicle traffic of a road on each experimental plots measured at peak hours in 2011 was respectively: $2320,1169,538$ vehicles per hour. Stabilized municipal sewage sludge from the Municipal Wastewater Treatment Plant in Sokolka was used. In autumn 2010 the test areas were fertilized with municipal sludge with two doses: 75 and $150 \mathrm{Mg} / \mathrm{ha}$ and control plots (without sewage sludge) were founded. The doses of sewage sludge do not exceed the maximum dose included in the Regulation [Regulation of the... 2010] in a single application of sewage sludge in two years (30 Mg DM/ha).
Municipal sewage sludge used in the experiment fulfill the requirements set out in the Regulation of Ministry of Environment of July $13^{\text {th }}$, 2010 concerning non-agricultural land recultivation [Regulation of... 2010].

\section{PAHs analyses}

The fluoranthene, pyrene, benzo[a]anthracene, chrysene, and benzo[a]pyrene in soil samples were carried out using a Varian 4000 GC/MS Gas Chromatograph with Mass Spectrometry, which was described in the Polish Standard (ISO 18287). The method of two-stage extraction was used.

\section{Physico-chemical and enzymatic analysis}

$\mathrm{pH}$ in soil samples taken from a depth of $0-20$ $\mathrm{cm}$ was determined by the potentiometric method in distilled water in ratio 1:2.5 (m:v). The organic carbon was measured by Tiurin method which is based on the oxidation of organic carbon by potassium dichromate in an acid medium and measurement of the excess dichromate using Mohr's salt [Ostrowska et al. 1991].

The enzyme activity was measured using the method of Casida et al. [Brzezińska and Włodarczyk 2005] by the reduction of 2,3,5-triphenyl tetrazolium chloride (TTC), to the red, water insoluble triphenylformazan (TPF), and the absorbance measured at $485 \mathrm{~nm}$ using a spectrophotometer to quantify TPF formation. Dehydrogenase activity was expressed as $\mu \mathrm{mol}$ TPF $\mathrm{g}^{-1}$ DM soil $20 \mathrm{~h}^{-1}$.

\section{Statistical analysis}

In order to test the effects of the experimental factors (dose of sewage sludge, year and localization) in the variables analyzed, a tree-way analysis of variance ANOVA with interaction term was performed. In case of significant F-tests, differences between group means were assessed by the Tukey post hoc test at significance level at $\mathrm{p}<0.05$. The correlation between characteristics was calculated using Pearson correlation (for $\mathrm{n}=$ 108) with the level of significance established at $\mathrm{p}<0.05$ and $\mathrm{p}<0.1$ by using Statistica 12.0.

\section{RESULT AND DISCUSSION}

The $\mathrm{pH}$ values for all samples tested ranged from 7.2 to 8.2 , which means that at each point alkalinity of the soil occurred (Table 1). The 
Table 1. Selected parameters of soil after application of different doses of sewage sludge $(0,75,150 \mathrm{Mg} / \mathrm{ha})$ measured in 2011 and 2012

\begin{tabular}{|c|c|c|c|c|c|c|}
\hline \multirow{2}{*}{$\begin{array}{c}\text { Sewage sludge dose } \\
{[\mathrm{Mg} / \mathrm{ha}]}\end{array}$} & \multicolumn{2}{|c|}{$\begin{array}{c}\mathrm{pH}_{\mathrm{H} 2 \mathrm{O}} \\
(\mathrm{min}-\mathrm{max})\end{array}$} & \multicolumn{2}{|c|}{$\mathrm{C}_{\text {org }}[\%]$} & \multicolumn{2}{c|}{$\begin{array}{c}\text { Dehydrogenase activity } \\
{\left[\mu \mathrm{\mu g} \text { TPF } / \mathrm{g} \mathrm{DM} \mathrm{20}^{-1}\right]}\end{array}$} \\
\cline { 2 - 7 } & 2011 & 2012 & 2011 & 2012 & 2011 & 2012 \\
\hline 0 & $7.6-8.0$ & $7.7-8.2$ & 1.11 & 1.39 & 0.20 & 0.42 \\
\hline 75 & $7.4-7.8$ & $7.6-8.2$ & 1.69 & 1.60 & 0.29 & 0.61 \\
\hline 150 & $7.2-7.6$ & $7.3-7.8$ & 2.07 & 1.58 & 0.26 & 0.72 \\
\hline Range & $7.2-8.0$ & $7.3-8.2$ & $0.45-3.30$ & $0.32-2.66$ & $0.12-0.40$ & $0.03-1,46$ \\
\hline
\end{tabular}

content of organic carbon was from 0.32 to $3.30 \%$ of dry soil and slightly higher contents were found for objects fertilized with sewage sludge. The dehydrogenase activity of soil was from 0.03 to $1.46 \mu \mathrm{g} \mathrm{TPF} \mathrm{g}^{-1} \mathrm{DM}$ of soil $20 \mathrm{~h}^{-1}$ and higher average values were reported in second year of the experiment.

Fluoranthene is one of the most abundant PAHs in the environment [Monte et al., 2012], that has a hydrophobic nature, tightly binds to soil particles and hence its bioavailability is very restricted [Yu et al., 2007]. The content of fluoranthene in soil was differentiated, but it was statistically insignificant (Figure 1). The experimental factors did not have a significant effect on this PAH. The average content of fluoranthene was the largest in soil without application of sewage sludge $(0.65 \mathrm{mg} / \mathrm{kg}$ DM of soil $)$ in samples taken in 2011 in Raginisa Str., while the smallest average content of fluoranthene was observed in the samples collected in 2011 in Hetmanska Str. and the highest dose of biosolids $(150 \mathrm{Mg} / \mathrm{ha})(0.17$ $\mathrm{mg} / \mathrm{kg}$ DM of soil) (Figure 1).

Schneider et al. [1996] show, that although pyrene is not classified as a carcinogen, it is an important mutagen prevalent in contaminated soils, and it is one of 16 PAHs on the USEPA list of priority contaminants that can pose a risk to human health because pyrene can transform to benzopyrene, which is toxic [White 2002]. Studies on the impact of different doses of sewage sludge on the concentration of pyrene in soil revealed reduction of this PAH in the object fertilized with sewage sludge, as compared to the control (Figure 1). The average largest concentration of pyrene was found in samples in Popieluszki Str. The average concentration of this PAH was largest in the soil samples collected in 2012 on control objects $(0.34 \mathrm{mg} / \mathrm{kg} \mathrm{DM}$ of soil), while the smallest results were obtained for the samples taken in 2011 on the plots with double dose of sewage sludge in Hetmanska Str. (0.12 mg/kg DM of soil).
We found that the concentration of benz[a] anthracene $(\mathrm{BaA})$ in soil varied, but the factors of experiment did not significantly influence this PAH (Figure 1). The largest average content of this PAH was observed in the soil samples taken in 2011 on control plots at Raginisa Str. $(1.00 \mathrm{mg} /$ $\mathrm{kg}$ DM of soil). The smallest concentration were obtained in 2012 for the control plots in Hetmanska Str. (0.03 mg/kg DM of soil).

It was found that the concentration of chrysene in soil shows significant effect of localization of experimental points and year of study (Figure 1). The average largest concentration of chrysene was obtained in 2012 on the control plots in Raginisa Str., while the lowest were noted in 2012 on the plots without sludge at Hetmanska Str. (0.09 and $0.74 \mathrm{mg} / \mathrm{kg}$ DM of soil, respectively).

Haritash and Kaushik [2009] reported that benzo[a]pyrene is considered to be carcinogenic and most toxic of the PAHs from waste petrochemical. Our results obtained for concentration of benzo[a]pyrene $(\mathrm{BaP})$ show that the factors of experiments did not influence this PAH (Figure 1). The largest concentration on $\mathrm{BaP}$ was observed in 2011 for the plots without sludge in Raginisa Str. (0.79 mg/kg DM of soil), while the lowest results were obtained in 2011 for the plots with a double dose of sludge in Hetmanska Str. $(0.21 \mathrm{mg} / \mathrm{kg}$ DM of soil).

Our results show, that the concentration of studied PAHs was mainly the effect of the location of research objects. Generally the highest concentrations in Raginisa and Popiełuszki Strs. were observed [Figure 1]. According to Banger et al. [2010] PAHs released in the vehicle exhaust are deposited in the nearby soils and their contents decrease exponentially with an increase in distance from roads. This study does not support our research, where in the case of Raginisa Str. objects are located far from the road (the distance was $15 \mathrm{~m}$ ), moreover, it was the area with the least traffic. 


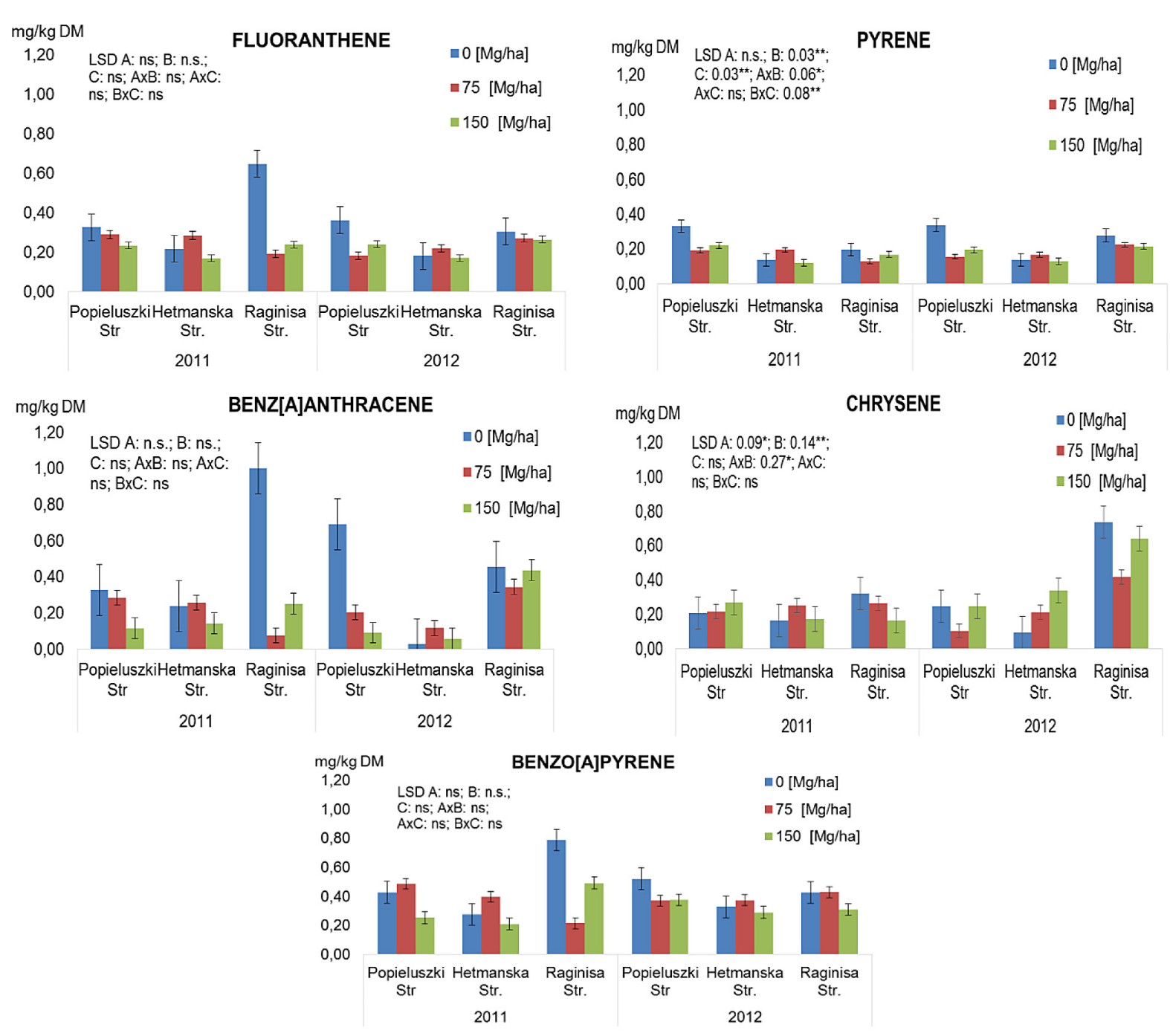

Figure 1. Concentration of fluoranthene, pyrene, benz[a]anthracene, chrysene, and benz[a]pyrene in soil samples collected in 2011 and 2012 on the Popieluszki, Hetmanska and Raginisa Strs. after application of different doses of sewage sludge $(0,75,150 \mathrm{Mg} / \mathrm{ha})$ (A: year, B: localization, C: dose of sewage sludge, ns - not significant differences, ${ }^{* *}$ significant differences for $\mathrm{p}<0.01 ; *$ for $\mathrm{p}<0.05$ )
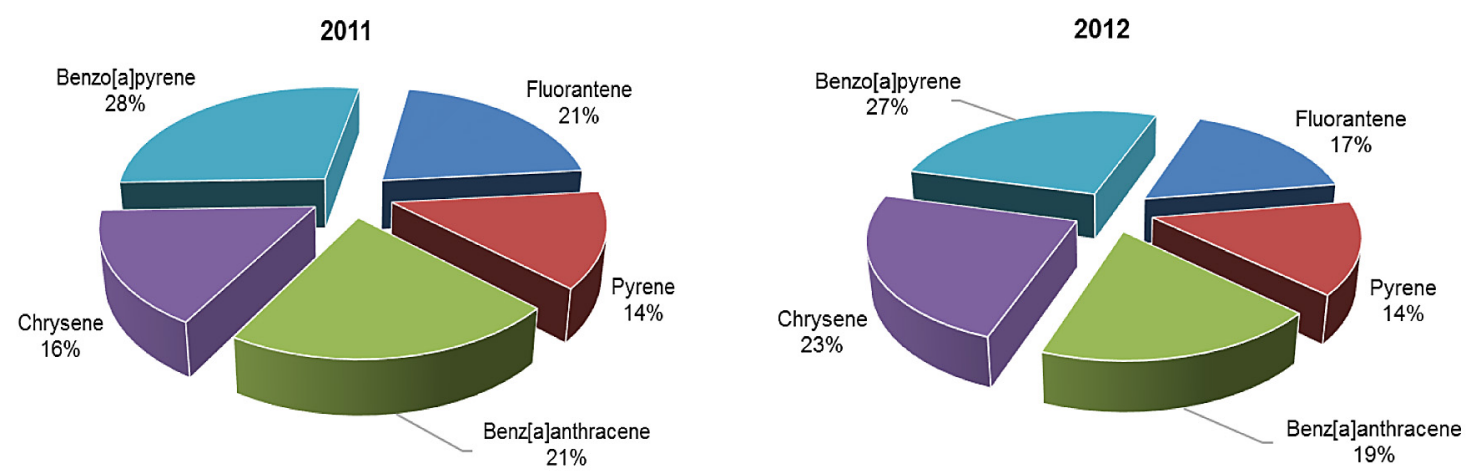

Figure 2 Share of average concentration of fluoranthene, pyrene, benz[a]anthracene, chrysene, and benz[a] pyrene in soil samples collected in 2011 and 2012

The obtained content of studied PAHs in the urban soil does not exceed those contained in the Regulation of the Minister of the Environment of September $9^{\text {th }}, 2002$ on soil quality standards and ground quality standards for Group C - industrial areas, utilities fossil and communication areas. Their content in the soil should not exceed $50 \mathrm{mg} /$ $\mathrm{kg}$ DM of soil [Regulation of...2002].

Among 5 tested PAHs compounds, benzo[a] pyrene was the most dominant compound both in 
Table 2. The correlation coefficients between selected properties of soil and selected PAHs content

\begin{tabular}{|l|c|c|c|}
\hline \multicolumn{1}{|c|}{ The parameters } & $\mathrm{pH}_{\mathrm{H} 2 \mathrm{O}}$ & $\mathrm{C}_{\text {org }}$ & Dehydrogenase activity \\
\hline Fluoranthene & 0.26 & -0.22 & -0.07 \\
\hline Pyrene & 0.20 & -0.07 & 0.02 \\
\hline Benzo[a]anthracene & $0.33^{* *}$ & -0.17 & 0.00 \\
\hline Chrysene & $0.28^{*}$ & -0.22 & $0.50^{* *}$ \\
\hline Benzo[a]pyrene & 0.24 & -0.08 & -0.08 \\
\hline
\end{tabular}

* Significant correlation coefficients for $\mathrm{p}<0.1$ and $* *$ for $\mathrm{p}<0.05$.

samples collected in 2011 and 2012 (28 and 27\%, respectively). It was found the lowest share of pyrene. It was showed an increase in the share of chrysene in 2012 in comparison with 2011 (Figure 2). Research The Voivodship Inspectorates for Environmental Protection indicate to exceed benzo[a]pyrene in the air in Bialystok [http:// www.wios.bialystok.pl...], which can be a major factor influencing the content of this PAHs in soil. Banger et al. [2010] reported the higher content of chrysene and pyrene may be attributed to more vehicle traffic in urban areas as chrysene and pyrene are a constituent of tire abrasion and are considered as typical indicator of combustion processes.

It demonstrated a positive correlation of medium strength $(\mathrm{r}=0.5)$ and high significance $(p<0.05)$ between dehydrogenase activity and chrysene. Other correlations, significant for $\mathrm{p}<0.05$, have low strength (Table 2).

$\mathrm{pH}$ affects the microbial degradation of PAHs. Dehydrogenase (DH) has been proposed as an indicator of overall microbial activity since it is an intracellular enzyme related to oxidative phosphorylation processes. Application organic wastes such as sewage sludge to soil stimulates DH activity because the input material may contain intracellular and extracellular enzymes and may also stimulate soil microbial activity [Zhang et al. 2012].

According to Dębska et al. [2014] and Banach-Szott et al. [2012], one of the important parameter which determines the immobilization of PAHs by soils is the quantity and the quality of organic matter. Organic matter is characterized by large sorption capacity and the stability of hydrocarbons in the soil depends largely on the process. As a result of sorption decreases their mobility and availability of PAHs for microorganisms. In our study, there was no significant correlation between the concentration of organic carbon in the soil and the studied PAHs. Probably, due to the low content of organic carbon in studied soils (Table 1). According to Zhang et al. [2012] organic wastes such as sewage sludge have been considered to be an effective solution to stimulate the indigenous microbial population and enhance their PAHs metabolic capability. The authors show also that the organic matter plays an important role in PAHs biodegradation through contribution of soil nutrients as a result of their mineralization and by stimulating microbial activity. It must be remembered that organic wastes are always rich in dissolved organic matter and the presence of its in the aqueous phase could decrease the sorption of PAHs, and thus influence their mobility [Yu et al. 2011]

\section{CONCLUSIONS}

Changes in concentration of fluoranthene, pyrene, benz[a]anthracene, chrysene, and benz[a] pyrene in urban soil samples depended on the location of experimental lawns and the year of study. Statistically significant differences were observed in the case of pyrene and chrysene.

Statistically significant differences were found in pyrene concentration depending on the dose of sewage sludge. Sewage sludge fertilization on urban soil caused reduction of pyrene concentration as compared to control plots which may be the result of microbial degradation or migration caused by the presence of dissolved organic matter in sewage sludge.

Among 5 tested PAHs compounds, benzo[a] pyrene was the most dominant compound in the samples collected in both 2011 and 2012. An increase in the share of chrysene in 2012 as compared with 2011 was found. High level these PAHs in soil may be attributed to more vehicle traffic in urban areas and can be considered as a typical indicator of incomplete burning of fuel or can enter the soil via atmospheric deposition.

\section{Acknowledgement}

This work was done with financial support of project MB/WBiIŚ/14/2014 and S/WBiIŚ/3/2015. 


\section{REFERENCES}

1. Banach-Szott M., Dębska B., Mroziński G. 2012. Zmiany zawartości wybranych WWA w glebach płowych. Proceedings of ECOpole, 6, 1, 173-181.

2. Banger K., Toor G.S., Chirenje T., Ma L. 2010. Polycyclic aromatic hydrocarbons in urban soils of different land uses in Miami, Florida. Soil and Sediment Contamination, 19, 231-243.

3. Baran S., Bielinska J.E., Oleszczuk P. 2004. Enzymatic activity in an airfield soil polluted with polycyclic aromatic hydrocarbons. Geoderma, 118, 221-232.

4. Brzezińska M., Włodarczyk T. 2005. Enzymy wewnątrzkomórkowych przemian redoks (okydoreduktazy). Acta Agrophysica, Rozprawy i Monografie, 3, 11-26.

5. De Nicola F., Alfani A., Maisto G. 2014. Polycyclic aromatic hydrocarbon contamination in an urban area assessed by Quercus ilex leaves and soil. Environmental Science and Pollution Research, 21, 7616-7623.

6. Dębska B., Banach-Szott M., Rosa E. 2014. Soil pollution of selected PAHs as a factor affecting the properties of humic acids. Journal of Ecological Engineering, 15, 1, 67-73.

7. Haritash A.K., Kaushik C.P. 2009. Biodegradation aspects of polycyclic aromatic hydrocarbons (PAHs): A review. Journal of Hazardous Materials $169,1-15$.

8. http://www.wios.bialystok.pl/?go=pub

9. Monte M.J.S., Notario R., Pinto S.P., Ferreira L., Ana I.M.C, R. da Silva, 2012. Thermodynamic properties of fluoranthene: an experimental and computational study. Journal of Chemical Thermodynamics, 49, 159-164.

10. Ostrowska A., Gawliński S., Szczubiałka Z. 1991. Metody analizy i oceny właściwości gleb i roślin. Katalog. IOŚ, Warszawa.

11. Piekutin J. 2011. Zanieczyszczenie wód produktami naftowymi. Rocznik Ochrony Środowiska, 13, 2, 1905-1916.

12. Rosales E., Pe'rez-Paz A., Va'zquez X., Pazos M., Sanroma'n M.A. 2012. Isolation of novel benzo[a]anthracene-degrading microorganisms and continuous bioremediation in an expanded-bed bioreactor. Bioprocess and Biosystems Engineering, 35, 851-855.
13. Rozporządzenie Ministra Środowiska z dnia 13 lipca 2010r w sprawie komunalnych osadów ściekowych (Dz.U. $2010 \mathrm{nr}$ 137, poz. 924)

14. Rozporządzenie Ministra Środowiska z dnia 9 września 2002 r. W sprawie standardów jakości gleby oraz standardów jakości ziemi (Dz.U. 2002 nr 165, poz. 1359).

15. Schneider J., Grosser R., Jayasimhulu K., Xue W., Warshawsky D. 1996. Degradation of pyrene, benzo[a]anthracene, and benzo[a]pyrene by mycobacterium sp. strain RJGII-135, isolated from a former coal gasification site. Applied and Environmental Microbiology, 62, 13-19.

16. Vane C.H., Kim A.W., Beriro D.J., Cave M.R., Knights K., Moss-Hayes V., Nathanail P.C. 2014. Polycyclic aromatic hydrocarbons (PAH) and polychlorinated biphenyls (PCB) in urban soils of Greater London, UK. Applied Geochemistry, 51, 2014, 303-314.

17. Wang Y., Tian Z., Zhu H., Cheng Z., Kang M., Luo C., Li J., Zhang G. 2012. Polycyclic aromatic hydrocarbons (PAHs) in soils and vegetation near an e-waste recycling site in South China: Concentration, distribution, source, and risk assessment. Science of the Total Environment, 439, 187-193.

18. White P.A. 2002. The genotoxicity of priority polycyclic aromatic hydrocarbons in complex mixtures. Mutation Research, 515, 85-98.

19. Wild S.R., Jones K.C. 1995. Polynuclear aromatic hydrocarbons in the United Kingdom environment: a preliminary source inventory and budget. Environmental Pollution, 88, 91-108.

20. Yu H, Huang G H, An C J, Wei J, 2011. Combined effects of DOM extracted from site soil/compost and biosurfactant on the sorption and desorption of PAHs in a soil-water system. Journal of Hazardous Materials, 190(1-3), 883-890.

21. Yu H., Zhu L., Zhou W. 2007. Enhanced desorption and biodegradation of phenanthrene in soil-water systems with the presence of anionic-nonionic mixed surfactants. Journal of Hazardous Materials, 142, 354-361.

22. Zhang J., Lin X., Liu W., Wang Y., Zeng J., Chen H. 2012. Effect of organic wastes on the plantmicrobe remediation for removal of aged PAHs in soils. Journal of Environmental Sciences, 24, 8, 1476-1482. 